\title{
Forms of violence experienced by Polish adult population. A brief report.
}

\author{
Milena A Guziak \\ mguziak@thelostchilhood.com.pl \\ https://www.thelostchildhood.com.pl
}

\begin{abstract}
Violence is a worldwide phenomenon affecting individuals across the globe resulting in mental health implications. Poland has a system in place for people experiencing domestic violence called the Blue Card procedure, from which the prevalence of domestic violence can be understood. However, not every act of violence take place is this context. A national survey on the prevalence of violence and frequency of reporting indicates that only $60 \%$ of those who witnessed abuse reported it to the police. This suggests that many cases go unreported and that the scale of violence is much wider. Thus, the aim of the study was to investigate the prevalence of different forms of violence: emotional (EV), physical (PV), and sexual (SV) among Polish population. A total of 234 adults were recruited through the Facebook platform, of which majority were women (87.2\%). The age of participants varied between 18 and 65 . The mean age was $22.52(S D=6.65)$. The frequency of physical violence among participants was 56.8 $\%$, which accounts for 133 cases. As for the emotional and sexual violence, the former amounts to $76.1 \%$ and the latter to $41 \%$. Almost $85 \%$ of all the participants been subjected to at least one form violence. A total of $3.4 \%$ had been subjected to PV, $3.4 \%$ to SV, $14.1 \%$ to EV. Almost $40 \%$ experienced two forms of violence and $25.2 \%$ three forms. The research found significant association between PV and EV, $\chi^{2}(1)=30.4, \mathrm{p}<.001$; between PV and SV, $\chi^{2}(1)$ $=6.4, \mathrm{p}<.05$ and EV and SV, $\chi^{2}(1)=9.6, \mathrm{p}<.05$. The implication of the present research is that it demonstrates the scale of violence and the violence dynamics among Polish population. By being aware of the co-occurrence of many forms of violence, we may begin to fully understand the complexity of this phenomenon and imagine the harm the violence causes.
\end{abstract}

Keywords: sexual violence, physical violence, emotional violence, Poland 


\section{BACKGROUND ON VIOLENCE IN POLAND}

Violence is a worldwide phenomenon affecting individuals across the globe resulting in mental health implications (Carey et al. 2018; Loncar, Henigsberg, \& Hrabac, 2010; Mechanic, Weaver, \& Resick, 2008; Sharma et al. 2019). Several forms of violence can be distinguished: physical, sexual, emotional, psychological, economic. Motivated by numerous forces, interpersonal violence occurs in various context: domestic, intercultural, school violence, intimate partner violence. The literature consistently indicates that women are more vulnerable to it (Borumandnia et al., 2020; World Health Organization [WHO], 2021).

Poland has a system in place for people experiencing domestic violence called the Blue Card procedure, associated with The Blue Line Association - a national emergency service for victims of domestic violence, according to the regulation of the Council of Ministers (Rada Ministrów, 2011; Dz.U. 2011 nr 209 poz. 1245). Excluding 2021 data, the Blue Card procedure shows a decreasing tendency. In 2020, police officers filled out 72601 Blue Card forms, which accounts for a decrease of $2.3 \%$ (74 313) compare with the year of 2019 and $2.25 \%$ (73 153) with 2018 (Biuro Prewencji KGP, 2021). However, a national report $(N=1000)$ on the prevalence of violence and frequency of reporting indicates that only $60 \%$ of those who witnessed abuse reported it to the police. This suggests that many cases go unreported and that the scale of violence is more prevalent (Ministerstwo Spraw Wewnętrznych, 2015). The same report inquired also about the reasons for not reporting it: $21 \%$ of the respondents said that family problems should be solved at home, $20 \%$ that reporting would be useless anyway; every eighth respondent said that it was not his business, and $8 \%$ was afraid of formalities. It is also important to notice that that every third person out of all respondents did not know any organization that provides assistance to victims of domestic violence.

Taking into consideration that many cases of abuse go unreported, the author sought to investigate the prevalence of different forms of violence (emotional, physical and sexual) among adult Polish population.

\section{METHODS}

\section{Participants}

After removing two participants who did not meet inclusion criteria and two who did not complete the questionnaire, a total of 234 adults were recruited through the Facebook platform. The age of participants varied between 18 and 65. The mean age was $22.52(S D=6.65)$. The full characteristics of the sample are shown in Table 1.

\section{Materials and Measures}

A questionnaire consisted of socio-demographic questions, questions related to forms of violence: physical (PV), emotional (EV), and sexual violence (SV). The participants were asked the following questions:

1) Have you ever in your lifetime experienced physical violence?

2) Have your ever in your lifetime experienced emotional violence?

3) Have you ever in your lifetime experienced sexual violence? 


\section{Equipment}

IMP SPSS Statistics software, version 27, for MacBook Pro was used to analyse quantitative data obtained from a survey created in Google Forms.

\section{Procedure}

A questionnaire with instructions was advertised on Facebook between June 9 and 15, 2020. Using Google Forms, each participant completed demographic questions related to forms of violence experienced: physical, emotional (psychological) and childhood sexual abuse (CSA). Those who were sexually abused as children were redirected to questions on consequences the abuse had on them and more details questions on types of CSA experienced. Those who had no such experiences were redirected to a section investigating public opinion on attitude towards the presents of psychologists in education system and what should be done to prevent CSA. The questionnaire was then closed, data transferred to a SPSS spreadsheet, after which it was deleted from Google Forms. The present study report on the forms of violence experienced, excluding self-inflicted forms of violence. The report on characteristics of childhood sexual abuse has been published already (Guziak, 2020). Other research reports in relation to the project will be published soon.

\section{Data Analysis}

Data was analysed using descriptive statistics such as percentage and frequency. Contingency tables were used to examine association between forms of violence.

\section{Ethics}

All participants were fully informed about what they will be asked to do, about the topic of the study and its sensitive nature and potential psychological effect by participating in the study, about what will happen to the data gathered according to GDPR, who and how to contact should they have any questions, and exclusion and inclusion criteria. In every section of the questionnaire, they were reminded about their right to withdraw from the study and how to proceed in case of any unexpected feelings or reaction. Consent was obtained from participants through a Consent Form included in the questionnaire. The participants were asked to complete all sections of the online form, which included confirming that they have read the Participant Information, are aware that their participation is voluntary and they have 2 weeks to withdraw from the study, that they are over eighteen, agree to take part in the study and have read and agreed to how their data will be used and understand what the research team's obligations are to them regarding their data. As the participants have been recruited online they had to tick all the boxes in the Consent Form in order to participate in the study. During the debrief process participants were once again asked to consent to their data being used at the end of the questionnaire. Deception was not used in this study. No request has been in relation to withdrawing their data from the study. Participants were informed that they will not be mentioned by name and their responses will be made anonymous and kept onfidential at all times. They were given a unique code at the beginning of the study, which was used if any of participants wish to withdraw. Participants' information has been stored on a passwordprotected computer. No request has been made so far in relation to withdrawing the data from the study. After the data was transferred to a SPSS sheet, it was removed from Google Forms. 


\section{RESULTS}

\section{Descriptive Statistics}

The mean age of participants in this study was $22.52(S D=6.65)$ years ranging from 18 to 65 years, of which majority were women $(87.2 \%)$. In terms of the highest education level obtained, majority of them completed education on the secondary level (63.2\%). In terms of occupation, the majority of participants were students/pupils (57.3\%). In terms of relationship status, almost half was in a non-married relationship (43.2\%) and almost half was single (45.7 $\%$ ) and $88.5 \%$ were childless (Table 1 ).

\section{Forms of Violence Experienced}

The frequency of physical violence among participants was $56.8 \%$, which accounts for 133 cases. As for the emotional and sexual violence, the former amounts to $76.1 \%$ and the latter to $41 \%$ (Table 2).

\section{Frequency of Multiple Victimization}

Table 3 depicts eight different subgroups of multiple victimization; a) those who experienced three forms of violence in their lifetime, b) two forms of violence, c) one form of violence, and d) none. The results of this study shows that almost $85 \%$ of all the participants been subjected to at least one form violence. A total of $3.4 \%$ had been subjected to PV, $3.4 \%$ to SV, $14.1 \%$ to EV. Almost $40 \%$ experienced two forms of violence and $25.2 \%$ three types (Table 3 ).

\section{Violence Association}

A Pearson's chi-squared test was performed to explore the association between various forms of violence. There was a significant association between PV and EV, $\chi^{2}(1)=30.4, p<.001$. There was a significant association between PV and SV, $\chi^{2}(1)=6.4, \mathrm{p}<.05(\mathrm{p}=.01)$ and significant association between EV and SV, $\chi^{2}(1)=9.6, p<.05(p=.002)$. 
Table 1

Participants Characteristics

\begin{tabular}{|c|c|c|c|}
\hline & & $\begin{array}{c}\text { Frequency }(\mathrm{N}=234) \\
\mathrm{n}(\%)\end{array}$ & $\begin{array}{l}\text { Mean Age } \\
\text { (SD) }\end{array}$ \\
\hline \multirow[t]{7}{*}{ Gender } & Female & $204(87.2)$ & $22.62(6.88)$ \\
\hline & Male & $17(7.3)$ & $23.00(6.15)$ \\
\hline & Non-binary & $5(2.3)$ & $18.50(1.00)$ \\
\hline & Gender fluid & $2(0.9)$ & $22.00(1.41)$ \\
\hline & Demigirl & $2(0.9)$ & $21.50(3.53)$ \\
\hline & Agender & $1(0.4)$ & - \\
\hline & Prefer not to say & $3(1.3)$ & $20.33(2.08)$ \\
\hline \multirow[t]{6}{*}{ Age } & $18-20$ & $111(47.4)$ & $18.92(0.81)$ \\
\hline & $21-30$ & $103(44.0)$ & $22.88(2.12)$ \\
\hline & $31-40$ & $16(6.8)$ & $36.00(3.08)$ \\
\hline & $41-50$ & $1(0.4)$ & - \\
\hline & $51-60$ & $1(0.4)$ & - \\
\hline & $61-70$ & $2(0.9)$ & $64.00(1.41)$ \\
\hline Employment & Employed & $50(21.4)$ & $24.80(6.01)$ \\
\hline \multirow[t]{9}{*}{ Status } & Self-employed & $6(2.6)$ & $30.67(7.17)$ \\
\hline & University Student & $121(51.7)$ & $20.41(1.88)$ \\
\hline & Student/Pupil & $13(5.6)$ & $18.42(0.64)$ \\
\hline & Full-time Parent & $8(3.4)$ & $25.00(6.54)$ \\
\hline & Unemployed & $30(12.8)$ & $22.00(5.36)$ \\
\hline & Retired & $2(0.9)$ & $64.00(1.41)$ \\
\hline & Annuity & $2(0.9)$ & $51.50(10.60)$ \\
\hline & Parental Leave & $1(0.4)$ & - \\
\hline & Medical Leave & $1(0.4)$ & - \\
\hline Highest Level of & Doctoral Level & $3(1.3)$ & $46.00(14.73)$ \\
\hline \multirow[t]{8}{*}{ Education } & Master Level & $28(12)$ & $33.34(10.49)$ \\
\hline & Bachelor Level & $20(8.6)$ & $24.15(2.62)$ \\
\hline & $\begin{array}{l}\text { Vocational Level (5-year } \\
\text { training) }\end{array}$ & $31(13.2)$ & $20.86(2.31)$ \\
\hline & High School Level & $117(50)$ & $20.29(3.02)$ \\
\hline & Post High-School Level & $25(10.7)$ & $21.40(1.78)$ \\
\hline & $\begin{array}{l}\text { Vocational Level (3-year } \\
\text { Training) }\end{array}$ & $1(0.4)$ & - \\
\hline & Primary School Level & $9(3.8)$ & $18.55(1.03)$ \\
\hline & Prefer not to say & $2(0.9)$ & $18.00(0.00)$ \\
\hline \multirow[t]{3}{*}{ Marital Status } & Single & $107(45.7)$ & $20.93(3.68)$ \\
\hline & Relationship (non-married) & $101(43.2)$ & $21.21(3.52)$ \\
\hline & Married & $26(11.1)$ & $34.15(12.10)$ \\
\hline \multirow{2}{*}{ Parental Status } & With Children & $27(11.5)$ & $32.92(12.93)$ \\
\hline & Without Children & $207(88.5)$ & $21.14(3.56)$ \\
\hline
\end{tabular}


Table 2

Forms of Violence Experienced by Gender, Age, Employment, Education, Marital and Parental Status $(N=234)$.

\begin{tabular}{|c|c|c|c|c|}
\hline Characteristics & & PV & $\mathrm{EV}$ & SV \\
\hline \multirow[t]{2}{*}{ Total $(\mathrm{N}=234)$} & Yes & $133(56.8)$ & $178(76.1)$ & $96(41.0)$ \\
\hline & No & $101(43.2)$ & $56(23.9)$ & $138(59.0)$ \\
\hline \multirow[t]{6}{*}{ Gender } & Female & $118(88.7)$ & $158(88.8)$ & $88(91.6)$ \\
\hline & Male & $7(5.3)$ & $8(4.5)$ & $3(3.1)$ \\
\hline & Non-binary & $4(3.0)$ & $5(2.8)$ & $2(2.1)$ \\
\hline & Gender fluid & $1(0.7)$ & $2(1.1)$ & $1(1.0)$ \\
\hline & Demigirl & $1(0.7)$ & $2(1.1)$ & $1(1.0)$ \\
\hline & Prefer not to say & $2(1.5)$ & $3(1.7)$ & $1(1.0)$ \\
\hline \multirow[t]{6}{*}{ Age } & $18-20$ & $61(45.9)$ & $90(50.6)$ & $39(40.5)$ \\
\hline & $21-30$ & $58(43.6)$ & $77(43.2)$ & $45(46.9)$ \\
\hline & $31-40$ & $11(8.3)$ & $8(4.5)$ & $8(8.3)$ \\
\hline & $41-50$ & $1(0.7)$ & $1(0.6)$ & $1(1.0)$ \\
\hline & $51-60$ & $1(0.7)$ & $1(0.6)$ & $1(1.0)$ \\
\hline & $61-70$ & $1(0.7)$ & $1(0.6)$ & $2(2.1)$ \\
\hline \multirow[t]{10}{*}{ Employment } & Employed & $34(25.6)$ & $37(20.8)$ & $22(22.9)$ \\
\hline & Self-employed & $2(1.5)$ & $4(2.2)$ & $4(4.2)$ \\
\hline & University Student & $56(42.1)$ & $92(51.7)$ & $42(43.8)$ \\
\hline & Student/Pupil & $9(6.8)$ & $11(6.2)$ & $5(5.2)$ \\
\hline & Full-time Parent & $5(3.7)$ & $5(2.8)$ & $4(4.2)$ \\
\hline & Unemployed & $22(16.5)$ & $25(14.0)$ & $14(14.5)$ \\
\hline & Retired & $1(0.7)$ & $1(0.6)$ & $2(2.1)$ \\
\hline & Annuity & $2(1.5)$ & $2(1.1)$ & $2(2.1)$ \\
\hline & Parental Leave & $1(0.7)$ & $1(0.6)$ & $1(1.0)$ \\
\hline & Medical Leave & $1(0.7)$ & - & - \\
\hline \multirow{7}{*}{$\begin{array}{l}\text { The Highest Level } \\
\text { of Education } \\
\text { Obtained }\end{array}$} & Doctoral Level & $1(0.7)$ & $1(0.6)$ & $2(2.1)$ \\
\hline & Master Level & $18(13.5)$ & $20(11.2)$ & $13(13.5)$ \\
\hline & Bachelor Level & $13(9.8)$ & $13(7.3)$ & $9(9.4)$ \\
\hline & $\begin{array}{l}\text { Vocational Level (5- } \\
\text { year training) }\end{array}$ & $18(13.5)$ & $24(13.5)$ & $15(15.6)$ \\
\hline & High School Level & $65(48.9)$ & $93(52.2)$ & $41(42.7)$ \\
\hline & $\begin{array}{l}\text { Post } \\
\text { Level }\end{array}$ & $11(8.3)$ & $18(10.1)$ & $9(9.4)$ \\
\hline & Primary School Level & $7(5.3)$ & $9(5.0)$ & $9(9.4)$ \\
\hline \multirow[t]{3}{*}{ Marital Status } & Single & $64(48.1)$ & $86(48.3)$ & $40(41.7)$ \\
\hline & $\begin{array}{l}\text { Non-married } \\
\text { Relationship }\end{array}$ & $50(37.6)$ & $76(42.7)$ & $41(42.7)$ \\
\hline & Married & $19(14.3)$ & $16(9.0)$ & $15(15.6)$ \\
\hline \multirow[t]{2}{*}{ Parental Status } & With Children & $20(15.0)$ & $17(9.5)$ & $14(14.5)$ \\
\hline & Without Children & $113(85.0)$ & $161(90.4)$ & $82(85.4)$ \\
\hline
\end{tabular}

Note. $\mathrm{PV}=$ Physical Violence, $\mathrm{EM}=$ Emotional Violence, $\mathrm{SV}=$ Sexual Violence 
Table 3

Single and Multiple Victimization $(N=234)$

\begin{tabular}{lc}
\hline $\begin{array}{l}\text { Forms } \\
\text { Violence }\end{array}$ & of \\
\hline PV + EV + SV & $59(25.2)$ \\
PV + EV & $60(25.6)$ \\
PV + SV & $5(2.1)$ \\
EV + SV & $26(11.1)$ \\
PV & $8(3.4)$ \\
EV & $33(14.1)$ \\
SV & $8(3.4)$ \\
None & $35(14.9)$ \\
TOTAL & $234(100)$ \\
\hline
\end{tabular}

Note. $\mathrm{PV}=$ Physical Violence, $\mathrm{EM}=$ Emotional Violence, $\mathrm{SV}=$ Sexual Violence

\section{DISCUSSION}

One of the aims of the research project was to investigate the prevalence. The result shows that frequency of physical violence among participants was $56.8 \%$, which accounts for 133 cases. As for the emotional and sexual violence, the former amounts to $76.1 \%$ and the latter to $41 \%$. Findings indicate that prevalence rates of all forms of abuse are high among Polish population, but its context was not investigated. Considering that a high number of cases occurs in family (domestic violence) and relationship settings (intimate partner violence, IPV), this may be the case for the present research as well (Elghossain et al., 2019; WHO, 2021). According to the existing body of evidence, women are more susceptible to experiencing violence (WHO, 2021). However, it is important to recognized that individuals of any gender and socio-economic status can be subject to aggression (Table 2). What is even more important is for psychological research to recognize the need of inclusion of other gender affiliations (Guziak, 2020).

The present study found that one form of violence may coexist with another one and that there is a significant association between different types of violence: PV with SV, PV with $\mathrm{EV}, \mathrm{EV}$ with SV. Other studies also found the cooccurrence of other forms of violence, however it is debatable which one is the main component of an act of violence itself as many possibilities are probable (Krebs et al. 2011). Additionally, cooccurrence of different forms of IPV is not limited to a single intimate relationship and single point in time (Garcia-Moreno et al., 2006). Furthermore, many research has reported on a significant relationship between different forms of violence: EV predicts the subsequent onset of PV (Murphy, \& O'Leary, 1989), PV and EV is significantly related to the the act of committing SV (Marshall, \& Holtzworth-Munroe, 2002), correlational relationship between all combinations of forms of 
violence (Rodenburg, \& Fantuzzo, 1993), non-intimate partner violence is linked to intimate partner violence (Krebs et al. 2011).

The implication of the present research is that it demonstrates the scale of violence and the violence dynamics among Polish population. By being aware of the co-occurrence of many forms of violence, we may begin to fully understand the complexity of this phenomenon and imagine the harm the violence causes.

\section{LIMITATIONS}

The study is not without limitations. It is clear that majority of participants were young adults of ages between 18-30 (91\%). There are several reasons for which older individuals did not take part in the study. The largest demographic group of Facebook users is between the ages of 25 and 35 years worldwide. Looking at specifically the period of time during which data was collected, in the month of June there were 19490000 Facebook users in Poland in June 2020, which accounted for $51.5 \%$ of its entire population. People aged 18 to 34 were the largest user group (47.3\%, www. napoleoncat.com). Whilst the statistical data indicate that the older demographic is also active on the platform, the author hypothesize there may exists other underlying reasons for which this age group and others would not be willing to participate in the study.

Another limitation of the study is related to forms of violence investigated. The author focused only on three forms, excluding economic violence and their severity. The context (domestic, school, work, race-motivated, intimate partner violence, etc.) of violence is very important when it comes to developing preventative and protective measures.

With the above limitations in mind, it is clear there is a need to look for methods to include older demographic and investigate further the dynamic of interpersonal aggression.

\section{REFERENCES}

Biuro Prewencjo KGP (2021). Informacja dotycząca realizacji przez Policję procedury „Niebieska Karta” w 2020.

Borumandnia, N., Khadembashi, N., Tabatabaei, M., \& Alavi Majd, H. (2020). The prevalence rate of sexual violence worldwide: a trend analysis. BMC public health, 20(1), 1835. https://doi.org/10.1186/s12889-020-09926-5

Carey, K. B., Norris, A. L., Durney, S. E., Shepardson, R. L., \& Carey, M. P. (2018). Mental health consequences of sexual assault among first-year college women. Journal of American college health : J of ACH, 66(6), 480-486. https://doi.org/10.1080/07448481.2018.1431915

Elghossain, T., Bott, S., Akik, C., \& Obermeyer, C. M. (2019). Prevalence of intimate partner violence against women in the Arab world: a systematic review. BMC international health and human rights, 19(1), 29. https://doi.org/10.1186/s12914-019-0215-5

Garcia-Moreno, C., Jansen, H. A., Ellsberg, M., Heise, L., Watts, C. H., \& WHO Multi-country Study on Women's Health and Domestic Violence against Women Study Team (2006). Prevalence of intimate partner violence: findings from the WHO multi-country study on 
women's health and domestic violence. Lancet (London, England), 368(9543), 1260-1269. https://doi.org/10.1016/S0140-6736(06)69523-8

Guziak, M. A., (2020). Child Sexual Abuse Among Polish Adult Population: Prevalence and Abuse Characteristics. Lost Childhood Association. https://doi.org/10.13140/RG.2.2.22674.27844

Krebs, C., Breiding, M. J., Browne, A., \& Warner, T. (2011). The association between different types of intimate partner violence experienced by women. Journal of Family Violence, 26(6), 487-500. https://doi.org/10.1007/s10896-011-9383-3

Loncar, M., Henigsberg, N., \& Hrabac, P. (2010). Mental health consequences in men exposed to sexual abuse during the war in Croatia and Bosnia. Journal of interpersonal violence, 25(2), 191-203. https://doi.org/10.1177/0886260509334288

Marshall, A. D., \& Holtzworth-Munroe, A. (2002). Varying forms of husband sexual aggression: Predictors and subgroup differences. Journal of Family Psychology, 16(3), 286296. https://doi.org/10.1037/0893-3200.16.3.286

Mechanic, M. B., Weaver, T. L., \& Resick, P. A. (2008). Mental health consequences of intimate partner abuse: a multidimensional assessment of four different forms of abuse. Violence against women, 14(6), 634-654. https://doi.org/10.1177/1077801208319283

Ministerstwo Spraw Wewnętrznych (2015). Przemoc w rodzenie - badanie MSW. Retrieved August 15, 2021, https://archiwum.mswia.gov.pl/pl/aktualnosci/12896,Przemoc-w-rodziniebadanie-MSW.html

Murphy, C. M., \& O'Leary, K. D. (1989). Psychological aggression predicts physical aggression in early marriage. Journal of Consulting and Clinical Psychology, 57(5), 579-582. https://doi.org/10.1037/0022-006X.57.5.579

NapoleonCat. Facebook users in Poland June 2020. Retrieved August 16, 2021. https://napoleoncat.com/stats/facebook-users-in-poland/2020/06/

Rada Ministrów (2011). Rozporządzenie Rady Ministrów z dnia 13 września 2011 r. w sprawie procedury "Niebieskie Karty" oraz wzorów formularzy "Niebieska Karta". Retrieved from http://isap.sejm.gov.pl/isap.nsf/DocDetails.xsp?id=WDU20112091245

Rodenburg, F. A., \& Fantuzzo, J. W. (1993). The measure of wife abuse: Steps toward the development of a comprehensive assessment technique. Journal of Family Violence, 8(3), 203228. https://doi.org/10.1007/BF00988769

Sharma, K. K., Vatsa, M., Kalaivani, M., \& Bhardwaj, D. (2019). Mental health effects of domestic violence against women in Delhi: A community-based study. Journal of family medicine and primary care, 8(7), 2522-2527. https://doi.org/10.4103/jfmpc.jfmpc_427_19

The Mindful Tourist. Forest Bathing Training and Wellbeing. https://www.themindfultourist.net 
World Health Organization (2021). Violence Against Women Prevalence Estimates, 2018. https://www.who.int/publications/i/item/9789240022256 